Journal of Southeast Asian

Volume 10

2015

\title{
Visualizing Social Influences on Filipino American and Southeast Asian American College Choice
}

\author{
Kristen Surla \\ Oberlin College, klsurla@gmail.com \\ Oiyan A. Poon \\ Loyola University Chicago, oiyan.poon@gmail.com
}

Forty and Forward: Research on the New Second Generation of Southeast Asian American Students

Vichet Chhuon

University of Minnesota

anthony lising antonio

Stanford University

Follow this and additional works at: https://docs.lib.purdue.edu/jsaaea

\section{Recommended Citation}

Surla, Kristen and Poon, Oiyan A. (2015) "Visualizing Social Influences on Filipino American and Southeast Asian American College Choice," Journal of Southeast Asian American Education and Advancement: Vol. 10 : Iss. 2, Article 4.

DOI: $10.7771 / 2153-8999.1132$

Available at: https://docs.lib.purdue.edu/jsaaea/vol10/iss2/4

This document has been made available through Purdue e-Pubs, a service of the Purdue University Libraries. Please contact epubs@purdue.edu for additional information.

This is an Open Access journal. This means that it uses a funding model that does not charge readers or their institutions for access. Readers may freely read, download, copy, distribute, print, search, or link to the full texts of articles. This journal is covered under the CC BY-NC-ND license. 


\title{
ISAAEA Journal of Southeast Asian American Education and Advancement
}

Vol. 10 Iss. 2 Special Issue (2015)

WWW.JSAAEA.org

\section{Visualizing Social Influences on Filipino American and Southeast Asian American College Choice}

\author{
Kristen L. Surla \\ Oberlin College \\ OiYan Poon \\ Loyola University Chicago
}

\begin{abstract}
This study identifies and explores social influences on the college choice process of Filipino American and Southeast Asian American high school seniors in an urban Midwestern setting. In an effort to contribute more depth to the knowledge regarding college choice among Filipino Americans and Southeast Asian Americans, this study engaged seven high school seniors in a photo elicitation study, allowing the students to tell their own stories of their pathways to college. Photos and follow-up interviews indicated that the students explicitly acknowledged kinship and peer networks as playing the most influential roles in the college choice process. Gender differences were found in how students understood their college choice experiences. Though not explicitly recognized by students in this study, college preparatory support programs and resources in the students' schools also provided important supports in navigating college-going systems.
\end{abstract}

Many Southeast Asian Americans and Filipino Americans are subjected to educational disparities and barriers to higher education access and advancement. Some Southeast Asian American populations experience significantly lower rates of college enrollment and attainment than all other racial and ethnic groups in the U.S. (Chang, Park, Lin, Poon, \& Nakanishi, 2007; National Commission on Asian American and Pacific Islander Research in Education [CARE], 2010; Teranishi, 2010). Slightly over 28 percent of the overall adult population older than 25 in the U.S. has earned at least a bachelor's degree according to American Community Survey, fiveyear demographic estimates reported by the U.S. Census Bureau. However, less than 15 percent of Cambodian, Laotian, and Hmong Americans over 25 years old have obtained at least a bachelor's degree (CARE, 2010). Although Filipino Americans have just slightly lower rates of bachelor's degree attainment (about 40\%) relative to Asian Americans as a whole (about 42\%)

(c)

SDIRERIGHISRESERNEDReaders are free to copy, display, and distribute this article, as long as the work is attributed to the author(s) and the Journal of Southeast Asian American Education \& Advancement, it is distributed for non-commercial purposes only, and no alteration or transformation is made in the work. More details of this Creative Commons license are available at http://creativecommons.org/licenses/by-nc-nd/3.0/. All other uses must be approved by the author(s) or JSAAEA.

Journal of Southeast Asian American Education \& Advancement, Vol. 10 Iss. 2 Special Issue (2015)

ISSN: 2153-8999 
(Chang et al., 2007), like Southeast Asian Americans they are more likely than other Asian Americans to enroll in less selective four-year colleges and two-year institutions (Buenavista, Jayakumar, \& Misa-Escalante, 2009; Teranishi, Ceja, antonio, Allen, \& McDonough 2004). This is concerning because research suggests that enrollment in less selective institutions can lead to lower rates of college completion and thus advanced degree attainment (CARE, 2011). Despite these indicators of inequality, there remains limited research exploring how these disparities in college access are produced that could inform efforts to advance equity.

The presented study, therefore, contributes toward research on the college pathways and college-going experiences among Southeast Asian American and Filipino American students. Utilizing a qualitative photo elicitation method, the study engaged in an in-depth exploration of the college choice experiences through the reflective perspectives of seven college-bound high school seniors from the Chicagoland area. The study's findings illustrate how differences in social capital can shape Filipino and Southeast Asian American students' college options and pathways. Social capital, or resources that facilitate and transmission of information about social systems like education, can play important roles in immigrant communities (Park, 2012; Pérez \& McDonough, 2008; Yosso, 2005). For students in this study, social capital generally consisted of their social networks, educational support systems, and school contexts. Some of these students' experiences were also gendered, with women and men presenting different perspectives on their college-going experiences. The study results challenged the individual oriented lens through which college choice is often conceptualized, and highlights the importance of college-going as a community-oriented process for Southeast Asian and Filipino American students. With a focus on these specific ethnic groups, the study also brings much needed attention to how these populations navigate college pathways, and sheds light on potential ways to better support diverse Asian Americans through their college-going experiences.

\section{Literature Review}

College choice research literature has contributed toward an understanding of students' diverse contexts of opportunity, and complex ways they gain access to and employ various resources to construct and navigate their pathways to college. A relatively limited, but growing, amount of research has explored college choice for Asian Americans. Some research has found that on the whole Asian Americans have very high academic aspirations (An, 2010), strongly value parental opinions (Goyette \& Xie, 1999), but are less likely than their white peers to be admitted at their first choice institution (Hurtado, Inkelas, Briggs, \& Rhee, 1997). These findings suggest a racialized Asian American narrative of high academic achievement buttressed by parental opinions and support, but still defined by their status as racial minorities. It is important to note that these studies did not bring attention to the vast demographic diversity found among Asian Americans, which can bear substantial differences in the college-going experiences between Asian American subgroups. More attention to nuances between and among diverse Asian American student identities and contexts of educational opportunities is needed to counter problematic assumptions of Asian Americans as a uniform racial group.

Although Asian Americans have often been treated as a monolithic racial group in the public discourse and in previous research on college choice, there exist notable differences by ethnicity and socioeconomic class in the college access and choice experiences of this diverse population (Teranishi et al., 2004). This growing area of research has found differences in college choice experiences by economic class (Teranishi, 2010), college-going generation and 
gender (Poon \& Byrd, 2013). External to individual student characteristics, research has also found that cultural and structural contexts matter in influencing how diverse Asian American students negotiate their pathways to college. For example, Park (2012) found that ethnic church communities can facilitate the exchange of information supportive of college access across economic class differences for Chinese Americans and Korean Americans. The type of high school attended can also affect how diverse Asian American students obtain information about college-going structures (Kim \& Gasman, 2011; Teranishi, 2010). Racial demographics of a high school also matter. Asian American students who attend schools that are predominately white and Asian American are more likely to have higher college eligibility rates than Asian American students attending predominately Black and Latino schools (Teranishi et al., 2004).

For Filipino and Southeast Asian American students specifically, research has found that they are significantly more likely than other Asian Americans to enroll in less selective institutions and in colleges closer to home instead of pursuing out-of-state options (Teranishi et al., 2004). This finding should not be taken lightly, since attendance at less selective institutions has been found to be correlated with lower college completion rates (Bowen \& Bok, 1998). This finding also suggests that academic undermatching, which "occurs when a student's academic credentials permit them access to a college or university that is more selective than the postsecondary alternative they actually choose" (Smith, Pender, \& Howell, 2013, p. 247) may be significant for determining outcomes in Filipino and Southeast Asian American choice, despite Smith and colleagues' (2013) finding that Asian American students are less likely than other students to experience an undermatch. These contradictory findings suggest the importance of further examining diverse Asian American group experiences in college choice using ethnically disaggregated data to better understand how disparities are produced.

Extant research has clearly demonstrated important differences in college-going patterns between diverse Asian American students. However, how these ethnic inequalities are produced remains a relatively under-researched question. Moreover, student perspectives on their experiences have rarely been centered in this research. Therefore, recognizing the importance of ethnic diversity among Asian Americans and their unique experiential perspectives, this study applied a photo elicitation method to contribute toward a better understanding of how disparities in Southeast Asian American and Filipino American college-going outcomes are produced. Applying a college choice model, described in the next section, the study explored how seven Southeast Asian American and Filipino American college-bound high school seniors navigated their college pathways. Through the reflective photographic lenses of these students, the study paid particular attention to key influences across various contexts in students' daily lives that guided and shaped their journeys toward college.

\section{Conceptual Framework}

Research to understand diverse college pathways has commonly applied the college choice model, which theorizes that students experience three stages in navigating pathways to college (Hossler \& Gallagher, 1987; Hossler, Schmit, \& Vesper, 1999). The first stage, predisposition, is concerned with how students develop intentions, or become predisposed, toward college attendance. Interest in going to college can be developed at different times for various students. In the next stage, search, information about college options is gathered from a variety of sources. In the third stage, choice, students, independently or with their families, make an enrollment decision often based on an assortment of factors deemed important. 
College choice scholarship has often recognized the important role of social capital in helping students and families navigate their particular contexts of educational opportunity, which can lead to divergent outcomes in college access and participation (McDonough, 1997; Perna, 2006). According to Yosso (2005), "social capital can be understood as networks for people and community resources. These peer and other social contacts can provide both instrumental and emotional support to navigate through society's institutions" including educational organizations (p. 79). For predominantly immigrant Asian American populations, research has recognized how ethnic community structures can facilitate the exchange of valuable college-going information, values, and aspirations across socioeconomic status differences (Park, 2012; Zhou, 2009).

Nonetheless, research has also recognized that many immigrant Asian American parents and families are limited in their technical capacity to support their children's completion of college-going requirements due to a lack of familiarity with the system of college access (Kim \& Gasman, 2011; Poon \& Byrd, 2013). Therefore, despite holding high collegiate aspirations for their children (An, 2010; Cho, Hudley, Lee, Barry, \& Kelly, 2008; Goyette \& Xie, 1999), many immigrant Asian American families may face substantial barriers to being directly involved in supporting their children's educational advancement (Lew, 2006; Louie, 2005; Portes \& Rumbaut, 2001). However, limitations in social capital among some immigrant Asian American parents and families should not be viewed as cultural deficits or hindrances to their children's educational pursuits. In being guided by the reflective perspectives of Cambodian American college students, Chhuon, Hudley, Brenner, and Macias (2010) highlighted the value of familial support in these students' educational endeavors, despite facing challenges in navigating between different expectations and contexts of support found between their families and in schools along their college pathways.

The valuable roles immigrant and refugee families play in the lives of Southeast Asian and Filipino American students, therefore, can be understood through Yosso's (2005) framework of community cultural wealth, which counters deficit conceptions of marginalized communities. The six forms of community cultural wealth, including aspirational, familial, social, navigational, resistant, and linguistic capital, represent "... an array of knowledge, skills, abilities and contacts possessed and utilized by Communities of Color to survive and resist macro and micro-forms of oppression" (Yosso, 2005, p. 77). This study acknowledges the various ways forms of community cultural wealth and social capital interact to inform Southeast Asian American and Filipino American students' college choice experiences. Given their experiences of college access disparities, how Southeast Asian Americans and Filipino Americans navigate college pathways embodies a form of resistance to the systemic reproduction of college access barriers they face.

Such complex interactions between social capital, community cultural wealth, and college choice processes are reflected in Perna's (2006) model of college choice. According to Perna (2006), an individual's college choice process can be determined by four contextual layers of context, which "recognizes differences across students in the resources that shape college choice" (p. 116). These four nested, contextual layers include the individual's habitus (i.e., demographic characteristics, cultural knowledge, value of college attainment, information about college, and assistance with college-going processes), the school and community context (i.e., availability of resources, types of resources, and structural supports and barriers related to college access), the higher education context (i.e., college marketing and recruitment, location, and institutional characteristics and actions to convey information), and the broader context of social, economic, and policy changes (Perna, 2006). Incorporating economic and sociological 
concepts, this model of college choice is “... useful for understanding differences across groups in college-choice outcomes, because of its explicit recognition of the multiple layers of context that influence an individual's college-related decisions" (Perna, 2006, p. 120).

However, Perna's model, like others, continues to center the individual student in a way that does not sufficiently acknowledge the importance of family members who may be integrally involved in a collective college decision making process. Challenging the individualistic orientation of these models, recent research focused on Latino college choice has highlighted how parents and families play vital roles in supporting Latino college access and persistence by applying Yosso's community cultural wealth framework to challenge deficit thinking (Alvarez, 2010; Ceja, 2006; Espino, 2015; Pérez \& McDonough, 2008). Like Latino families, some Asian Americans have been found to be guided by collectivist values (Kodama, McEwen, Liang, \& Lee, 2002). They have also been found to strategically deploy forms of community cultural wealth to resist structural marginalization and overcome adversities (Buenavista et al., 2009; Leong, Airriess, Li, Chen, \& Keith, 2007; Tang, Kim, \& Haviland, 2013). Therefore, utilizing the community cultural wealth framework to understand social capital, this study reframes and contributes toward research identifying how Southeast Asian and Filipino American college choice may be influenced by familial and communal social contexts.

\section{Methods and Data Collection}

Depending on how well different forms of capital and community cultural wealth translate into navigating existing systems of college entry, diverse students' pathways to college can range from being very smooth to very complicated and challenging. Such differences in the college choice process can explain divergent outcomes in college-going patterns experienced by diverse students (Perna, 2006). As such, this study aimed to identify and explore factors influencing Filipino American and Southeast Asian American high school seniors' experiences of navigating college choice pathways in the Chicago metropolitan area. Guided by the three stages of the college choice model, we articulated the following questions to direct this study.

1. What informs Filipino American and Southeast Asian American students' aspirations to pursue postsecondary education?

2. In the search stage of their college choice process, what characteristics of postsecondary education do these students prioritize in determining which colleges and universities to apply to?

3. What factors influence these students' choice to enroll in one postsecondary institution over others?

Informed by our conceptual framework, we deliberately focused on examining social contexts and how they may have influenced the students' college pathways through this study.

\section{Research Participants and School Settings}

A purposeful sampling technique (Patton, 2002) was utilized in recruiting Filipino and Southeast Asian American high school seniors navigating pathways to college at the two high schools. To recruit participants for the study, the first author visited a youth group meeting at a local Asian American community-based organization and student club meetings at Ignatius Preparatory School (Ignatius Prep), which is a private Catholic high school in suburban Chicago. At the time 
of the study, the first author was a college student who had previously participated in volunteer opportunities at the youth group and at Ignatius Prep. As a young Filipina American woman and Chicago local familiar with pre-existing professional relationships at both organizations, the first author was able to gain access to student meetings where she introduced the research project and invited students to participate. Printed handouts for the study containing a link to an online survey hosted on surveymonkey.com were distributed during meetings at both sites. The online survey asked students basic questions about their school environment, demographic information, and college choice process. It allowed us to select participants who matched the study's criteria for participation (i.e., Filipino American or Southeast Asian American high school senior currently going through the college admissions process) to invite and engage in photo elicitation interviews. The seven study participants included two Vietnamese Americans, one Cambodian American, and four Filipino American high school seniors from two different high schools in the Chicago metropolitan area.

Because school settings matter in influencing students' social capital for college-going and determining educational opportunities (Teranishi, 2010), we decided to limit the invitations to students from two local high schools which varied in their institutional type. This decision was informed by an interest in identifying differences that might result from dissimilar school settings with possible differences in college-going culture. A school exhibits a college-going culture when all school stakeholders, including students, staff, and families, believe that college is a realistic goal for students and commit resources and activities toward supporting students' collegiate endeavors (Griffin \& Buford, 2003).

In addition to Ignatius Prep, students from West Park High School, a neighborhood Chicago public high school where many of the youth group's members were enrolled, were invited to participate in the study. West Park serves a low income and very racially diverse area of Chicago. Its demographic diversity is representative of the high concentration of immigrant families from Eastern Europe, Asia, and Africa in the surrounding neighborhoods. The collegegoing atmosphere of West Park High School is representative of a traditional model (Hill, 2008), which offers limited resources for students who plan to pursue higher education. Ignatius Prep, on the other hand, is located in a wealthy, predominately White suburb. Its students are admitted through a selective enrollment process. It prides itself on its strong college-going environment and placement of $98 \%$ of its graduates in selective 4 -year colleges across the country.

\section{Data Collection and Analysis}

The recruitment process resulted in the inclusion of seven students who fit the study's criteria and were willing to participate in the duration of the study. Background information on each of the participants can be found in the appendix. Four students were enrolled at West Park High School: one Cambodian American female, one Filipina American female, and two Vietnamese American males. All of the students in the study from West Park were second generation immigrants, meaning that they were born in the United States to immigrant parents. They were also all members of the same local Asian American community-based organization youth group. Student participants enrolled at Ignatius Prep included three students who identified as second generation Filipino Americans. Two were female, and one was male.

Given our interest in centering students' reflective perspectives on their college-going experiences, we used a photo elicitation interview method, and invited the seven students to create a photo blog to illustrate and describe their experiences along their college-going 
pathways. Photo elicitation methods privilege research subjects' rather than researcher perspectives, and can produce more extensive and detailed interviews than conventional interview methods (Harper, 2002). Additionally, the imagery presented in participant-generated photos can have the advantage of facilitating memory recall for richer and more in-depth interviews (Harper, 2002). First developed by visual anthropologists and visual sociologists, photo elicitation has also been used in education research (Harper, 2002). Gubrium and Harper (2013) traced the development of photovoice, a participatory action research model of photo elicitation methods in education, to Brazilian educator Paolo Freire. In this study, we did not engage in a participatory action research approach and instead opted for a method that allowed students to share their stories of college-going and college choice through both photography and individual interviews guided by the photos they produced. We anticipated that our method of photo elicitation interviews would facilitate an engaging process for research participation that could enable a reflective, student-centered process of inquiry. As such, the students were prompted to discuss their experiences of navigating their college-going processes while acknowledging their particular social and cultural contexts presented in their images.

During the initial individual meeting with the first author, students were asked to answer the following questions using photographs:

1. How did you first hear about different opportunities for post-secondary education? Please take pictures that identify and symbolize the ways that you were introduce to higher education.

2. Think of the colleges to which you applied and take pictures that identify and symbolize the factors that influenced your decision to apply to these schools.

3. Take pictures that identify and symbolize the factors that contributed to your decision to enroll at the college/university you plan to attend in the next academic year.

As the students completed their collection of photography in response to the three prompts, they filled their individual password protected blogs with their photos. The blogs functioned to record their work and as a tool to organize and reference the students' photos during the follow up individual interviews. During the follow up individual interviews, students were asked to verbally explain the meanings behind each of their photos and to discuss their responses to the questions about their college choice processes. To establish trustworthiness of data, students' interview responses were summarized to verify meanings and encourage additional detail in the narratives (Creswell \& Miller, 2000). After transcribing the interviews, we deductively reviewed and open coded the photo elicitation interview data (Creswell, 2002) according to the three research questions. In this way, we aimed to ascertain commonalities and differences by ethnicity, gender, school attended economic class status, and college-going generation in how these students were experiencing the predisposition, search, and choice phases of college choice process.

\section{Findings}

The photo elicitation interviews allowed the seven students to visually illustrate and verbally explain how they experienced the college choice process. In each of the three stages of the choice process, students expressed important ways in which family and social networks influenced their exploration of post-secondary educational opportunities. Members of students' 
families and social networks played important and valued roles in shaping how students envisioned and defined higher education. Specifically, they played key roles in shaping these students' understandings of college as leverage for collective, not just individual, social mobility. While students in this study emphasized the importance of family and social networks in their college choice processes, there were noteworthy differences by gender and college-going generation in students' experiences of meaning-making along their college pathways. Students' pictures and photo elicitation interviews did not highlight the role of school contexts and resources. Nonetheless, students did mention how school personnel and resources provided support in their navigation and completion of technical tasks in applying to college and for financial aid. The remainder of this section presents details on the study's findings.

\section{Family and Friends Shaping College Visions in the Predisposition Phase}

How students define the purpose of pursuing and completing a college degree can play an important role in the predisposition phase of the college choice process, consequently shaping the meanings underlying their college goals. All seven students expressed a desire to attend a college or university after high school. They shared that their aspirations for pursuing higher education were shaped by their families. During each interview, the students disclosed that their parents encouraged them to think of college as a pathway to attain financial mobility. As such, they described education as a pathway for "a better life" for their families. For example, Jasmine, a Filipina American student from Ignatius Prep reflected,

my parents came from the Philippines and when they came here, they didn't have that much money, but they always worked hard to get where they are today and they always told me that you should always strive for a better education and exceed what we have now.

Despite Jasmine's more affluent background relative to other students in the study, she described her family's financial and social mobility as key reasons to obtain a college degree. Jonathan, a Vietnamese American student whose parents never attended college, shared a similar vision for obtaining postsecondary educational credentials. Describing a picture of his mother, he stated "My household is not wealthy, we live an okay life and I just want to make my mom's life better and my family's life easier." Because of the relationship between family and financial mobility, developing an aspiration for college among Filipino American and Southeast Asian American students was not a choice for individual students, but rather a decision for the well-being of the family as a whole.

\section{Parental Education Levels, Older Siblings, Cousins, and Predisposition}

A notable difference in the predisposition phase of college choice was seen according to the level of parents' education. Students whose parents did not attend college or acquired a college education outside of the United States identified siblings and cousins as influences in the development of their college aspirations. Four out of the seven students heavily emphasized the role of older siblings or cousins in how they developed goals to go to college. Among the students who identified siblings and cousins as important, the only similar characteristic was parental education. These four students' parents had lower levels of educational attainment 
compared to the other three. Only one of these four students had parents who had earned a bachelor's degree.

Observing the pursuit of higher education by their older siblings and cousins, Filipino American and Southeast Asian American students in this study were able to visualize the difference between higher education as an aspiration that their parents spoke about and a realistic future goal for themselves. A Vietnamese American student named Peter from West Park admitted:

Truth be told, I didn't even know that college existed until $6^{\text {th }}$ grade when my sister was talking about it. Really, I think my sister was the biggest influence in my life, because she went to college and I realized how much she enjoyed it and got out of it. So, that's really when I decided that I needed to go to college.

Similarly, Rafael, a Filipino male from Ignatius Prep shared, "I guess it [aspiration to go to college] would just lead back to my family.... I guess it was the same aspect, just seeing my cousins go through it and seeing that it was something that would happen." Heather, a Cambodian American female and Arianna, a Filipino American female, both from West Park acknowledged the significance of their older siblings who acted as role models to whom they could aspire to and ask advice from regarding college. Arianna recalled,

I learned through my sister's experience I guess because she would tell me about classes and stuff and things she would do outside of school. She's really active in a way that I want to be when I go to college.

While four of the students identified older siblings and cousins as key role models in their college pathways, two students with parents holding advanced degrees relied on family elders in their development of college aspirations and planning. Jasmine and Cristina, Filipina American students at Ignatius Prep, did not identify siblings or cousins as an integral part in developing college goals and preparing to be college ready. Both students had the privilege of developing their college aspirations and plans through out-of-school preparatory programs or college visits. Jasmine discussed a summer college preparatory course at Johns Hopkins for aspiring medical students that helped her become more familiar and comfortable with going to college. For Cristina, her parents and grandparents, who also have bachelor's degrees, encouraged her to consider applying to elite institutions such as Stanford and Yale by taking her on frequent college visits. Cristina's first picture on her photo blog depicts her with her three sisters at Stanford's picturesque campus during one of their family campus visits.

Differences in parental education levels delineated an inequality in their awareness of the range of college opportunities for students in this study. While family contexts served to shape students' development of collegiate aspirations, students with parents who were limited in their familiarity with accessing college relied more on older siblings and cousins for information. Students with family elders who had attended college and obtained advanced degrees possessed more resources to guide the development of their college aspirations and goal setting. 


\section{Family and Friends Matter during the Search for a "Good" College}

All seven students in the study discussed the ways siblings, cousins, and friends provided information to help identify postsecondary institutions to consider in the search phase of their college choice process. Rather than relying on available resources in their high school counseling centers, the students recognized individuals within their familial or peer networks for providing suggestions of colleges to consider. Six of the interviewed students acknowledged that their search for potential institutions to consider involved identifying where family members, friends, and community members enrolled. The only exception was Heather, a Cambodian American female from West Park who only considered very specific schools as dictated by her contract as a POSSE program scholarship recipient. In this case, the POSSE program staff guided the student through the search and choice phases. Discussing the photo in figure 1, Arianna, a Filipina American student from West Park, explained that there was something familiar and safe about going to schools that were reputable within her social networks:

I realized that I wanted to apply to different colleges in the city because this is what I've been used to and I chose to apply to Loyola, DePaul, UIC [University of Illinois Chicago] because I'm so used to it. Just hearing so many people in my high school, family, cousins, they go to UIC too and it's like a safety net for me, I guess. I applied there because that's what everyone else did. I guess I'll apply there because that's what my parents want. It's like all of my cousins graduate from West Park and go to Truman [neighboring community college]. They want me to stay here. And at first I thought that I can't imagine myself living without them because I'm really dependent on my family.

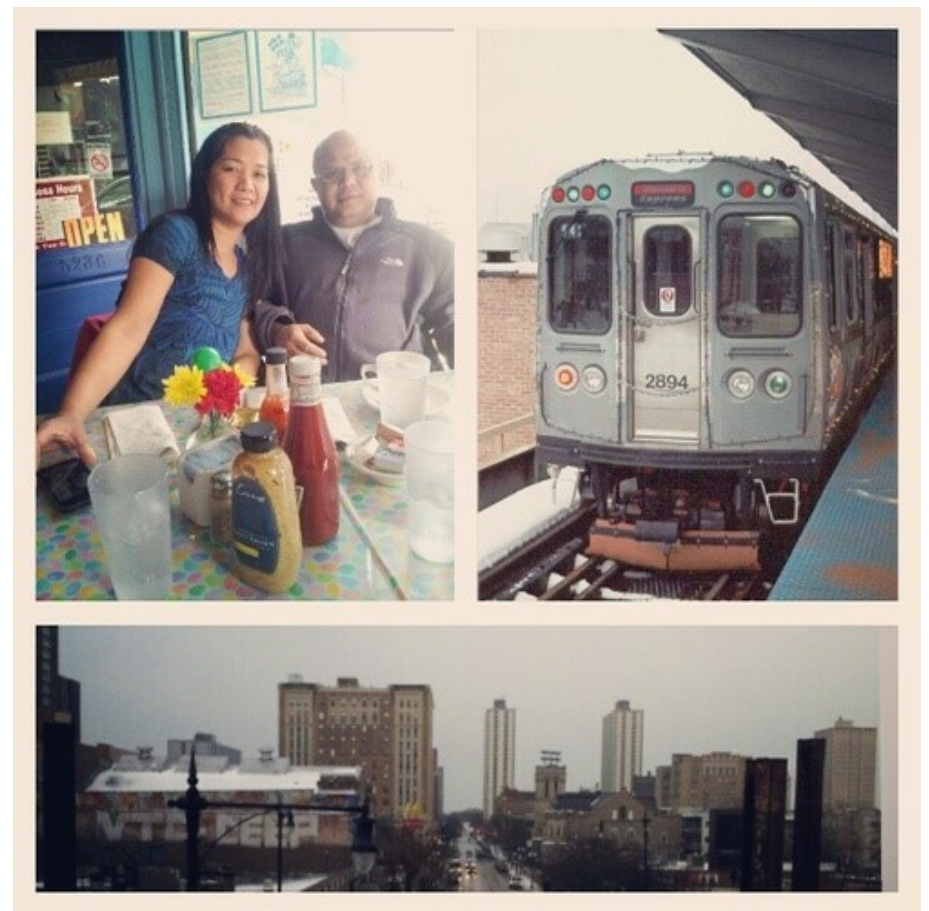

Figure 1 
After receiving feedback and suggestions about certain schools from family, friends, or other community members, students from West Park and Ignatius Prep were more inclined to consider the named postsecondary institutions as options in their search.

For some students, the opinions of their family and friends were more trustworthy than those of high school counselors. Contrasting his experiences with guidance counselors and family, Peter a Vietnamese male from West Park, reflected:

For my counselors, I would have to ask them again and again before they actually broke, because counselors would just say good things and then you would have to ask them again and be serious to give their own personal opinion as to how they feel and at that point, you would actually have to take that into consideration when you get your letters [of recommendation]. But for family, it's just cut and dry. You just ask them, and they tell you exactly how they think.

The experience of older friends also helped students with their search for potential schools. Students looked to the college-going trends of their peers who participated in similar cocurricular organizations or who held shared interests. Cristina, a Filipina American from Ignatius Prep, sought advice from older classmates she considered "older siblings" throughout high school. She explained, "My friend went to Loyola University Chicago and she was in [Asian Youth Group] too and she was like a big sister figure to me. So since she was going to Loyola, I looked at it as a good possibility too. And then my older sister was there for a year so that also influenced me as well." Even for students who explored potential out-of-state institutions, the opinions and feedback provided by older friends helped them identify potential colleges to consider in the search phase. To explain why she was considering Santa Clara University, Cristina shared, "My friend's older brother went to Santa Clara. Me and his older brother are very similar, like our work ethic and how we just kind of learn are very similar, so when I found out that's where he wanted to go, that's when I looked at it a lot more." The students in this study often viewed family and friends' opinions as more trustworthy than sources of information provided by their schools in their search for "good" colleges.

\section{Proximity to Family Matters in the College Search Phase}

Interviewed students also considered postsecondary institutions located in proximity to family members. They expressed that being located near immediate or extended family members during their college years was an important consideration in the search phase. In discussing the photo in figure 2, Rafael, a Filipino American student from Ignatius Prep explained:

Everywhere I go [in state or out of state] has a good core of people that I know, and I guess I just don't necessarily have to miss home while being away from home because I have people that I know and have with me in the general area of where I am going. 


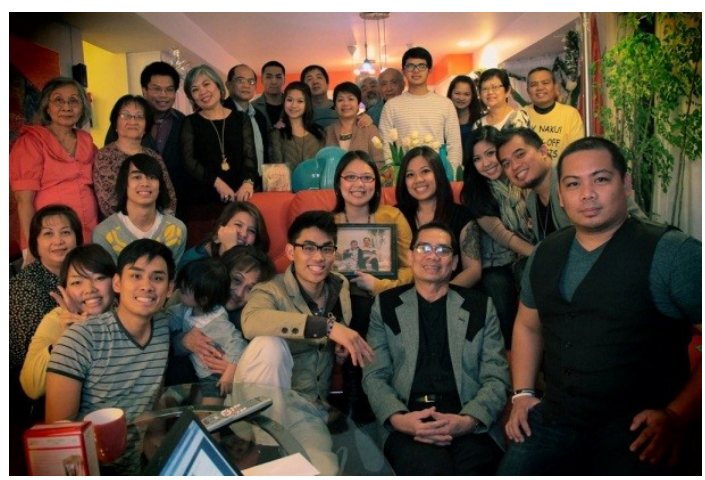

Figure 2

Rafael expected that family would provide an important support system in his pursuit of higher education. The other two male participants from West Park High School also stated that staying connected with family was a non-negotiable consideration for financial, emotional and personal needs. While some students also discussed strong interests in schools located far from family and friends, proximity to family seemed to win out in the end. Jonathan admitted, "Like MIT, everyone's got that dream school that they always want, but I kind of am like more of a family person and I like to stay close to the family."

While Cristina applied to the farthest school away from Chicago among this group of students, she disclosed that applying to Santa Clara University was still consistent with her condition to applying to schools that were close to family. Her grandparents' house was only a 10-minute drive from the Jesuit campus. For these Filipino American and Southeast Asian American students the college choice process was inherently bound to a value of maintaining family connectedness.

\section{Gender Differences along Pathways to College}

Looking at the interviews as a whole, the factors of financial aid, class size, and sense of community on a college campus were shared among all participants in the study. Aside from gender, no clear differences associated with a particular demographic characteristic emerged from the analysis. All seven participants mentioned financial aid playing a large role in their final decision making process. However, some noticeable gender differences emerged as we analyzed interview data. In particular, the men were more likely to state that the purpose of college was related to job training, while most of the women explained how college was a time for selfexploration. Additionally, the option to go away from home for college seemed to weigh more heavily on the women in the study as they contemplated choices.

For male students, going to college meant being able to obtain specific job goals they identified as important for life after college. Even on a campus visit, Jonathan explained that he made sure to identify the resources devoted towards helping students gain internship and work opportunities. In discussing the picture of a corporate conference room (figure 3), he recalled:

The first thing I thought of when picking a college is, "What is my likelihood of getting a job after I graduate?" One of the programs at [the Illinois Institute of Technology] that I applied to, they have job readiness all the time. They have workshops, job fairs every semester, and they help students that need help with interview skills. They host like events like that to help students. 


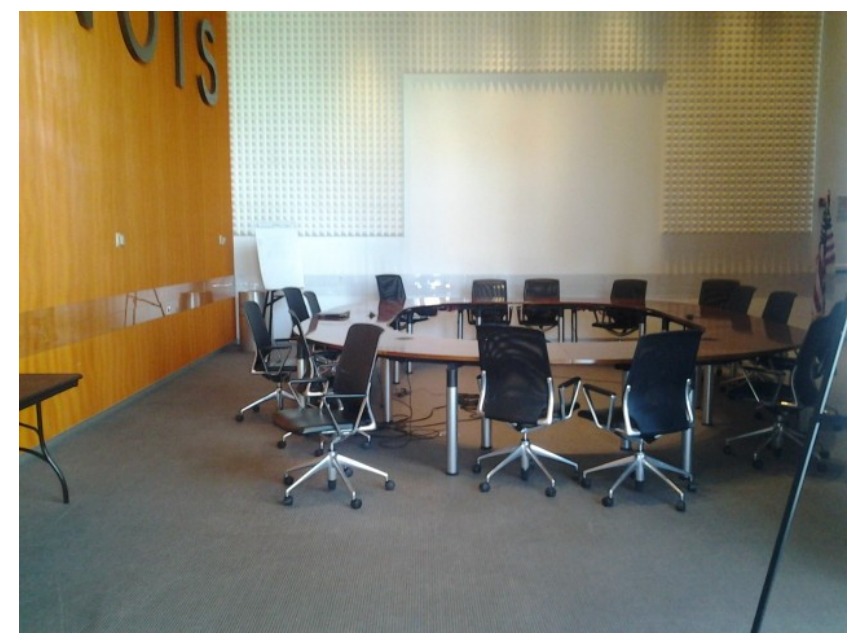

Figure 3

Similarly, the other two male students in the study also discussed the meaning of college in relation to their future career goals of becoming a mechanical engineer and a physical therapist.

When asked, "What does college mean to you?" three out of four of the women identified "exploration" and "self-discovery" as their purpose for going to college. Jasmine, the one female who differed from the other women viewed college as a means to a job. She had recently been accepted into a six-year physical therapy program. As such, going to college for her was vocationally focused. For the other female students, college was discussed as a kind of adventure. During the choice phase for these women, the idea of "finding oneself" became very important, and they seemed to struggle with deciding between their individual interests and the desire to stay close to their immediate families.

Gender differences again emerged in the discussion of the choice phase, when the possibility of moving away from home seemed to weigh heavier for the women than the men in the study. All four women struggled with the decision to pursue their higher education farther away from home. Moving away for the female students meant pursuing their need to explore and find themselves, pursuing their desired career paths, or making wise financial decisions for their families. For example, Arianna, a Filipina American student at West Park, struggled with her decision and reflected:

What worries me is adjusting to living on my own because I've never done that. My parents are so strict that they don't even let me sleepover at someone's house. I don't know how I would be able to adjust to that or handle that or I would be homesick or what. I'm able to perform well at school without them being in my room, just being in a whole different setting outside of the city, outside of my room, outside of my house. That's a whole different structure. What excites me is being able to find out what more of my interests are and be more confident about myself because I'm all alone without my family and friends at a different school. It would bring me more independence of course. I think that's what I want.

Arianna's description displayed one example of the deep sense of connectedness the female students had to their families. Cristina added her thoughts about leaving family and shared, 


\section{Surla, Poon - Visualizing Social Influences On College Choice}

My parents are another factor [in college choice]. My mother has separation issues with us. Even though my sister was at Loyola University Chicago, she would like cry almost every day and she would ask if she was coming home this weekend.

Heather's response, on the other hand, exhibited a very different college choice experience. As a participant in the POSSE program, Heather only applied to one school, guided by her participation in the program and scholarship restrictions. The financial support afforded through POSSE seemed to allow her to consider other reasons why she was looking forward to enrolling at her college. In discussing the factors that influenced her college choice, Heather presented a picture of lacrosse sticks (figure 4), and explained that "the biggest reason" for choosing her college was because it "...offers lacrosse. I fell in love with this game because of my best friend."

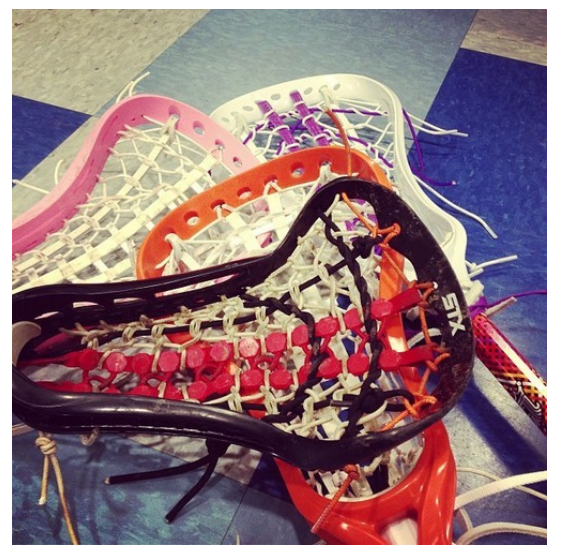

Figure 4

Overall though, the strong ties the female students had to their families were evident in their responses. For the female students in this study, the choice phase marked another moment when they were faced with the decision to make an individual choice within the context of familial roles, relationships, and expectations.

Interestingly, even though the female students struggled with the idea of leaving their families, all four enrolled in institutions located at least 200 miles away from home. Arianna chose to attend a rural school in Illinois to pursue a degree in environmental science. Cristina chose to attend Santa Clara University in California. Jasmine chose to attend Marquette University in Wisconsin. It is notable that both female students from Ignatius Prep, a Jesuit high school, enrolled at Jesuit postsecondary institutions. Heather was automatically accepted and enrolled at a private university in Indiana as contracted through her POSSE scholarship program participation. Although the female students ultimately chose to move away from home, it is important to remember that their initial attraction to those schools was a result of a connection to someone within their familial or peer networks. This finding seems consistent with the ways Cambodian American women have reconciled differences between gendered familial expectations and going away to college, by reinterpreting their experiences and decisions to be consistent with traditional cultural values (Chhuon, Kyratzis, \& Hudley, 2010).

In contrast to the female participants, male students from both West Park and Ignatius Prep chose to attend schools within 75 miles distance from their immediate families. The three male students applied to more schools that were closer to home than the women in the study. The institutions they identified during the search phase of college choice were almost all within the 
Chicagoland area and were recommended to them by someone in their family or peer networks who was familiar with that school. However, the men in the study did not clearly articulate a desire to remain close to family as a reason to limit their applications to institutions in relative proximity to home. One male student was accepted to out-of-state schools, but decided not to enroll based on finances rather than an unwillingness to leave his family.

\section{Unsung Schools Setting the Stage and Supporting College-Going}

Previous research on college choice has shown the importance of secondary institutions to the college-going opportunities available to students (Hill, 2008; Roderick et al., 2011; Teranishi, 2010). There were significant differences in the resources for and culture of college-going between Ignatius Prep and West Park High School. While important, high school settings and resources supporting college-going were not identified by students in this study through their photographs and interviews as playing significant roles in their pathways to college. We were particularly surprised that Ignatius Prep students did not identify the wealth of resources available to them in the study.

On the other hand, when specifically asked about their experiences of completing college and financial aid applications, students discussed how counselors, teachers, and other college preparation programs assisted with their basic understanding of things such as the Common Application and Free Application for Student Aid (FAFSA). School sponsored workshops they attended also helped familiarize them to the processes of transcript requests, obtaining letters of recommendation, writing application essays, and FAFSA. Additionally, Ignatius Prep students acknowledged attending Formation classes, a required twice-a-week course with the goal of developing college readiness among students. Ignatius Prep students also mentioned using Naviance, a technological tool that assists in the exploration of post-secondary opportunities. Although West Park students did not have access to programs like Formation or Naviance, all of the study participants from West Park were enrolled in the AVID (Achievement via Individual Determination) program or the POSSE Foundation program. Both of these programs support first-generation and low-income students, who have demonstrated academic promise, in their college-going aspirations.

Participation in college preparation programs like AVID and POSSE may have influenced the students to apply to more than four colleges and universities. The students in this study applied to more institutions than was average for Southeast Asian American and Filipino American students in a previous national study (Teranishi et al., 2004). Jonathan attributed his decision to apply to a larger list of schools to his participation in AVID, recalling "The AVID program pushed me to apply to more schools too. So when I make my decision, I would have more choices to make my decision than just three schools." Comparing their application experiences to some of their peers who were not in college readiness programs, students stated that they felt more prepared for the college application process. Curiously, despite applying to a larger list of schools, Jonathan claimed that the schools on his list were not influenced by AVID. Instead, as with all other students in the study, he explained that his interest in various postsecondary institutions was determined by his observations of where family and friends attended or suggested. 


\section{Discussion}

This study intentionally chose to bring attention to the college choice experiences of Filipino and Southeast Asian American students, to identify possible explanations of disparities in collegegoing among diverse Asian American populations. By focusing on two specific Asian American populations, we hoped to illuminate the influences and experiences of these two underserved ethnic groups along their pathways to college. Previous research has found that Filipino American and Southeast Asian American students tend to apply to a lower number of colleges and are more like to enroll in less selective institutions closer to home than their South and East Asian American peers (Teranishi et al., 2004). At the same time, other research has indicated that Asian Americans, on the whole, are more likely than other racial groups to apply to highly selective institutions (An, 2010) and are less likely to experience academic undermatch (Smith et al., 2013). Contrasting these research findings demonstrates the value of studying Asian Americans through ethnically disaggregated approaches.

This study utilized a photo elicitation interview approach to better understand the college choice experiences of seven Filipino and Southeast Asian American high school seniors from the Chicagoland region through their perspectives. Our analysis suggests that family, friends, and other community networks - social contexts - can influence roles on the college choice experiences of Filipino and Southeast Asian American students in three possible ways. First, family and friends played significant roles in defining the students' purposes for pursuing higher education in this study. Older siblings, cousins, and friends who attended college also served as role models for students, concretely demonstrating that college was a realistic goal. By encouraging students in the formation of college aspirations and goals, family and friends supported students in the predisposition phase of the college choice process. Secondly, in the search and choice phases of their experiences, students in this study identified family members and peers as important information sources in their identification of "good" colleges and universities to consider. Finally, the students in this study expressed a strong value to remain connected to family and friends, and subsequently limited their college choices to institutions located within relative proximity to immediate or extended family. The ways in which Filipino and Southeast Asian American college students' choices and experiences may be embedded within their contexts of family have been well documented by previous research (Chhuon, Hudley, Brenner, \& Macias, 2010; Fouad, Kantamneni, Smothers, Chen, Fitzpatrick, \& Terry, 2008; Maramba, 2008; Poon \& Byrd, 2013). Therefore, it is important to acknowledge the importance and value of family and community contexts for some students' college-going decisions and experiences.

The study also suggests that there may be differences in Filipino and Southeast Asian American student experiences navigating their pathways to college by gender. This finding echoes Poon and Byrd's (2013) finding of significant gender differences among Asian Americans in the college choice process. The men in this study expressed that the purpose of college was to obtain a job and secure career. While all students in the study viewed higher education as instrumental to obtaining upward mobility and financial security, the women did not solely view the purpose of college as a means to financial stability. They were more likely to view college as an opportunity for self-exploration. Perhaps as a consequence, the women also expressed some tensions in balancing the desire to be close to family with their individual interests for self-discovery and development of independence in college. Heather, the Filipina POSSE member from Ignatius Prep, was the exception to this gendered pattern. It is possible that 
her participation in the scholarship program, which provides a significant amount of guidance and financial benefits, influenced her understanding of college-going and opportunities.

The POSSE Foundation's influence on Heather's experiences is just one example of ways in which resources external to family and peer networks played unsung roles in supporting students' journeys into college. None of the students took pictures that explicitly or implicitly identified features of their school contexts as important in their college choice process. However, all seven of the students are enrolled in college preparation classes in their schools - AVID at West Park and Formation classes at Ignatius Prep - and mentioned or discussed these programs during their interviews. They also verbalized minimal acknowledgement of school resources as providing support in their navigation of admissions and financial aid procedures. Particularly for first generation college students, these resources were important in their completion of applications. This finding is reinforced by Poon and Byrd (2013), who claimed that firstgeneration college students cannot depend entirely on their families, since many of their parents were not as familiar with the college access process.

Students' oversight of the support provided by school resources may have been a function of a limitation of this study. The questions sought to understand how the students arrived at an understanding of the purposes of higher education, how they determined the institutions to which they applied, and ultimately at which to enroll. The question prompts presented to students did not ask for a specific identification of sources of information or supports available to them. Nonetheless, interview data did suggest that school resources and other educational programs are important in supporting Filipino and Southeast Asian American students along their pathways to college.

This study suggests that there may be boundaries between familial contexts and educational contexts in these students navigation of college access, potentially producing experiences of disjointedness. Accordingly, we can draw some implications for supporting the college access experiences of Filipino and Southeast Asian American students. First, it is important to acknowledge the ways in which these students' decisions may be significantly shaped by the contexts of and in relationship with their families and social networks. As demonstrated by previous research on Southeast Asian American students, transitions into college are not just student transitions, but should also be recognized as whole family transitions (Chhuon, Hudley, Brenner, \& Macias, 2010; Chhuon, Kyratzis, \& Hudley, 2010). This important acknowledgement serves to extend current college choice models and literature, which tend to view college choice as a solitary individual decision making process. It also highlights the value of the community cultural wealth framework for studying the experiences of Asian Americans in higher education. Additionally, it suggests the importance of considering college transitions through a more holistic frame that recognizes the valuable and unique ways students' families participate in the college-going process. Secondly, to bridge potential divides between school and family contexts, educators might also consider culturally-relevant ways to improve engagement with families in providing information about higher education. Some Southeast Asian and Filipino American family members, who might identify as refugees or immigrants, may require information provided in appropriate languages. Partnerships between schools and local ethnic community organizations may facilitate and help families learn about diverse higher education opportunities.

Additional research is also required to improve and contribute toward knowledge about college-going and attainment outcomes of these diverse, and often overlooked, populations, to improve practice and policy. Future research should continue utilizing qualitative research 
methods to contribute toward a deeper understanding and knowledge of Southeast Asian and Filipino American student experiences in navigating their pathways to college. In particular, future research should seek to better understand gender differences among these diverse students' experiences of college access. While many scholars have called for ethnic disaggregation in research on Asian Americans, this study and others have found intriguing gender differences that have yet been well explored by research. While some scholarship exploring gender and Asian American college students has been published (Maramba, 2008; Shek \& McEwen, 2012; Tran \& Chang, 2013), there remains little research providing in-depth understandings of any differences between the experiences of Asian American men and women in the college choice processes.

\section{Conclusion}

Southeast Asian American and Filipino American students in this study explicitly identified the importance of familial and social networks in their pathways to college. In addition to informing their understandings of the purpose of higher education, families and peers were influential in naming "good" colleges and universities to consider in these seven students' college choice processes. The students' considerations of college opportunities also strongly accounted for proximity to trusted family and friends. Although the students highlighted the importance of their families, some women in this study were faced with reconciling familial expectations with the prospects of going away for college and using their time to develop independence and engage in self-exploration. Finally, while the students in this study did not explicitly identify resources in their schools as playing critical roles in their experiences, many did discuss their participation in various programs as important in completing requirements in the college admission process. The disjuncture between school and family contexts suggests that for some Southeast Asian and Filipino American students, an intentional bridging of these important contexts could help improve college choice experiences and access. This study suggests that for some Filipino and Southeast Asian American students, college access and attainment is not just an individual experience or decision, but rather a more collective experience.

\section{References}

Alvarez, C. L. (2010). Familial negotiation of the Latina college choice process: An exploration of how parents and their daughters obtain and utilize information to navigate the process. Enrollment Management Journal, 4(4), 57-80.

An, B. P. (2010). The relations between race, family characteristics, and where students apply to college. Social Science Research, 39(2), 310-323.

Bowen, W. G., \& Bok, D. (1998). The shape of the river: Long-term consequences of considering race in college and university admissions. Princeton, NJ: Princeton University Press.

Buenavista, T. L., Jayakumar, U., \& Misa-Escalante, K. (2009). Contextualizing Asian American education through critical race theory: An example of U.S. Pilipino college student experiences. New Directions for Institutional Research, 142 (2009), 69-81.

Ceja, M. (2006). Understanding the role of parents and siblings as information sources in the college choice process of Chicana students. Journal of College Student Development, 47(1), 87-104. 
Surla, Poon - Visualizing Social Influences On College Choice

Chang, M. J., Park, J. J., Lin, M. H., Poon, O. A., \& Nakanishi, D. T. (2007). Beyond myths: The growth and diversity of Asian American college freshmen, 1971- 2005. Los Angeles, CA: UCLA Higher Education Research Institute.

Chhuon, V., Hudley, C., Brenner, M. E., \& Macias, R. (2010). The multiple worlds of successful Cambodian American students. Urban Education, 45(1), 30 -57.

Chhuon, V., Kyratzis, A., \& Hudley, C. (2010). Sources of coherence in the life stories of Cambodian American women at the university. Journal of Language, Identity \& Education, 9(5), 347-362. doi:10.1080/15348458.2010.517702

Cho, S. J., Hudley, C., Lee, S., Barry, L., \& Kelly, M. (2008). Roles of gender, race, and SES in the college choice process among first-generation and nonfirst-generation students. Journal of Diversity in Higher Education, 1(2), 95-107.

Creswell, J. W. (2002). Research design: Qualitative, quantitative, and mixed methods approaches (2nd ed.). Thousand Oaks, CA: Sage Publications.

Creswell, J. W., \& Miller, D. L. (2000). Determining validity in qualitative inquiry. Theory Into

Practice, 39(3), 124-130.

Espino, M. M. (2015). Our college choice: Uncovering a familial- and culturally-based college decision-making process. A community of higher ed scholars: The official blog of AERA Division J. Retrieved from: http://aeradivisionj.blogspot.com/2015/02/our-collegechoice-uncovering-familial.html

Fouad, N. A., Kantamneni, N., Smothers, M. K., Chen, Y.-L., Fitzpatrick, M., \& Terry, S. (2008). Asian American career development: A qualitative analysis. Journal of Vocational Behavior, 72(1), 43-59.

Goyette, K., \& Xie, Y. (1999). Educational expectations of Asian American youths: determinants and ethnic differences. Sociology of Education, 72(1), 22-36.

Griffin, K. A. \& Buford, M., III. (2009). Working with what you have: College preparation at a low-resourced high school. In W. R. Allen, E. Kimura-Walsh, and K. A. Griffin (Eds.), Towards a brighter tomorrow: College barriers, hopes and plans of Black, Latina/o and Asian American students in California (pp. 59-82). Charlotte, NC: Information Age Publishing, Inc.

Gubrium, A., \& Harper, K. (2013). Participatory visual and digital methods. Walnut Creek, CA:

Left Coast Press.

Harper, D. (2002). Talking about pictures: A case for photo elicitation. Visual Studies, 17 (1), 13 $-26$.

Hill, L. D. (2008). School strategies and the 'college-linking' process: Reconsidering the effects of high schools on college enrollment. Sociology of Education 81(1), 53-76.

Hossler, D., \& Gallagher, K.S. (1987). Studying student college choice: A three-phase model and the implications for policymakers. College and University 62(3), 207-21.

Hossler, D., Schmit, J. L., \& Vesper, N. (1999). Going to college: How social, economic, and educational factors influence the decisions students make. Baltimore, MD.: Johns Hopkins University Press.

Hurtado, S., Inkelas, K. K., Briggs, C., \& Rhee, B.-S. (1997). Differences in college access and choice among racial/ethnic groups: Identifying continuing barriers. Research in Higher Education, 38(1), 43-75.

Kim, D., \& Gasman, M., (2011). In search of a 'good college': Decisions and determinations behind Asian American students' college choice. Journal of College Student Development 52(6), 706-728. 
Surla, Poon - Visualizing Social Influences On College Choice

Kodama, C., McEwen, M., Liang, C., \& Lee, S. (2001). A theoretical examination of psychosocial issues for Asian Pacific American students. Journal of Student Affairs Research and Practice, 38(4). doi:10.2202/1949-6605.1150

Leong, K. J., Airriess, C. A., Li, W., Chen, A. C., \& Keith, V. M. (2007). Resilient history and the rebuilding of a community: The Vietnamese American community in New Orleans East. Journal of American History, 94, 770-779.

Lew, J. (2006). Asian Americans in class: Charting the achievement gap among Korean American youth. New York, NY: Teachers College Press.

Louie, V. (2004). Compelled to excel: Immigration, education, and opportunity among Chinese Americans. Palo Alto, CA: Stanford University Press.

Maramba, D. C. (2008). Immigrant families and the college experience: Perspectives of Filipina Americans. Journal of College Student Development, 49(4), 336-350.

McDonough, P. M. (1997). Choosing colleges: How social class and schools structure opportunity. Albany, NY: SUNY Press.

National Commission on Asian American and Pacific Islander Research in Education. (2010). Federal higher education policy priorities and the Asian American and Pacific Islander community. New York: National Commission on Asian American and Pacific Islander Research in Education. from: http://www.nyu.edu/projects/care/docs/2010_CARE_Report.pdf

National Commission on Asian American and Pacific Islander Research in Education. (2011). The relevance of Asian Americans and Pacific Islanders in the college completion agenda 2011. New York, NY: National Commission on Asian American and Pacific Islander Research in Education. Retrieved from: http://care.gseis.ucla.edu/assets/2011_care_report.pdf

Park, J. J. (2012). It takes a village (or an Ethnic economy) The varying roles of socioeconomic status, religion, and social capital in SAT preparation for Chinese and Korean American students. American Educational Research Journal, 49(4), 624-650.

Patton, M. Q. (2002). Two decades of developments in qualitative inquiry: A personal, experiential perspective. Qualitative Social Work, 1(3), 261-283.

Pérez, P. A., \& McDonough, P. M. (2008). Understanding Latina and Latino college choice: A social capital and chain migration analysis. Journal of Hispanic Higher Education, 7(3), 249-265. doi:10.1177/1538192708317620

Perna, L. W. (2006). Studying College access and choice: A proposed conceptual model. In J. C. Smart (Ed.), Higher Education: Handbook of Theory and Research: Vol. XXI (pp. 99157). Netherlands: Springer.

Poon, O. A., \& Byrd, A. (2013). Beyond tiger mom anxiety: Ethnic, gender, and generational differences in Asian American college access and choices, The Journal of College Admission, 221, 22-31.

Portes, A., \& Rumbaut, R. G. (2001). Legacies: The story of the immigrant second generation. Berkeley, CA: University of California Press.

Roderick, M., Coca, V., \& Nagaoka, J. (2011). Potholes on the road to college: High school effects in shaping urban students' participation in college application, four-year college enrollment and college match. Sociology of Education, 84(3), 178-211.

Shek, Y. L., \& McEwen, M. K. (2012). The relationships of racial identity and gender role conflict to self-esteem of Asian American undergraduate men. Journal of college Student Development, 53 (5), 703 - 718. 
Surla, Poon - Visualizing Social Influences On College Choice

Smith, J., Pender, M., \& Howell, J. (2013). The full extent of student-college academic undermatch. Economics of Education Review, 32, 247 - 261.

Tang, J., Kim, S., \& Haviland, D. (2013). Role of family, culture, and peers in the success of first-generation Cambodian American college students. Journal of Southeast Asian American Education \& Advancement, 8, 1-19.

Teranishi, R. T. (2010). Asians in the ivory tower: Dilemmas of racial inequality in American higher education. New York, NY: Teachers College Press,

Teranishi, R. T., Ceja, M., Antonio, A. L., Allen, W.R., \& McDonough, P.M. (2004). The college-choice process for Asian Pacific Americans: Ethnicity and socioeconomic class in context. The Review of Higher Education 27(4), 527-551.

Tran, M. C., \& Chang, M. J. (2013). To be mice or men: Gender identity and the development of masculinity through participation in Asian American interest fraternities. In S. D. Museus, D. C. Maramba, \& R. T. Teranishi (Eds.), The misrepresented minority: New insights on Asian Americans and Pacific Islanders, and the implications for higher education (pp. 67 - 85). Sterling, VA: Stylus Publishing.

Yosso, T. (2005). Whose culture has capital? A critical race theory discussion of community cultural wealth. Race and Ethnicity in Education, 8(1), 69-91.

Zhou, M. (2009). Contemporary Chinese America: Immigration, ethnicity, and community transformation. Philadelphia, PA: Temple University Press. 


\section{Appendix}

Participants

\begin{tabular}{|c|c|c|c|c|c|}
\hline Pseudonym & Gender & Ethnicity & $\begin{array}{l}\text { High } \\
\text { School }\end{array}$ & $\begin{array}{l}\text { Mother's } \\
\text { Education }\end{array}$ & $\begin{array}{l}\text { Father's } \\
\text { Education }\end{array}$ \\
\hline Arianna & $\mathrm{F}$ & Filipina & West Park & High School/ GED & High School/ GED \\
\hline Heather & $\mathrm{F}$ & Cambodian & West Park & High School/ GED & Some college \\
\hline Jonathan & $\mathrm{M}$ & $\begin{array}{c}\text { Ethnically } \\
\text { Chinese, } \\
\text { Vietnamese }\end{array}$ & West Park & $\begin{array}{l}\text { Never attended } \\
\text { high school }\end{array}$ & unknown \\
\hline Peter & $\mathrm{M}$ & Vietnamese & West Park & $\begin{array}{c}\text { Did not finish high } \\
\text { school }\end{array}$ & $\begin{array}{l}\text { Did not finish high } \\
\text { school }\end{array}$ \\
\hline Cristina & $\mathrm{F}$ & Filipina & $\begin{array}{l}\text { Ignatius } \\
\text { Prep }\end{array}$ & Bachelor's & Master's \\
\hline Jasmine & $\mathrm{F}$ & Filipina & $\begin{array}{l}\text { Ignatius } \\
\text { Prep }\end{array}$ & Master's & $\begin{array}{l}\text { Currently } \\
\text { completing } \\
\text { Master's }\end{array}$ \\
\hline Rafael & $\mathrm{M}$ & Filipino & $\begin{array}{l}\text { Ignatius } \\
\text { Prep }\end{array}$ & Bachelor's & Bachelor's \\
\hline
\end{tabular}




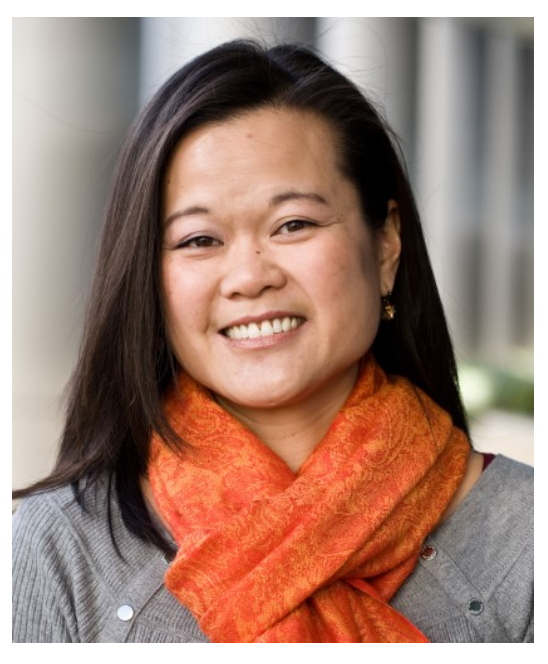

Dr. OiYan Poon is an Assistant Professor of Higher Education at Loyola University Chicago. Her research interests focus on racial inequalities in college access, affirmative action, and Asian Americans. Committed to community-based research, Dr. Poon's research agenda is informed by her previous professional experiences as the first Asian Pacific American Student Affairs director at George Mason University and the first Student Affairs Officer in Asian American Studies at UC Davis. She was also a key advocate for the establishment of the federal AANAPISI (Asian American Native American Pacific Islander Serving Institution) designation. She earned her Ph.D. in education with a certificate in Asian American Studies from UCLA.

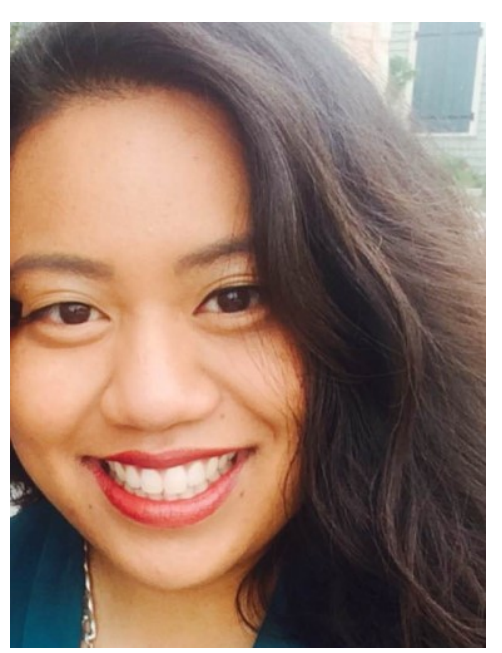

Kristen Surla is the Assistant Director of the Multicultural Resource Center \& Asian/Pacific Islander Diaspora Community Coordinator at Oberlin College \& Conservatory. Since graduating from Loyola University Chicago in 2013 with a B.A. in Sociology and English, she has continued her professional interests working with Asian/Pacific Islander communities in higher education. Currently, Kristen's work at Oberlin prioritizes critical social justice education through the connection of curricular and co-curricular experiences on campus. Her professional and research interests in education compromise of the intersections of race, queerness, immigration, and college access. 


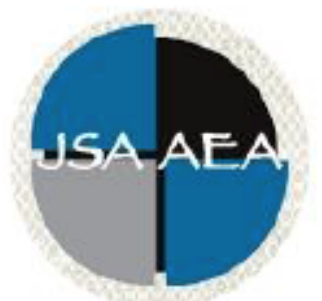

Vol. 10 Iss. 2 Special Issue (2015)

\section{Journal of Southeast Asian American Education and Advancement}

www.JSAAEA.org

\section{Special Issue Editors}

Vichet Chhuon

University of Minnesota

anthony lising antonio

Stanford University

\section{Editor}

Dr. Wayne E. Wright

Purdue University

\section{Associate Editors}

Dr. Chhany Sak-Humphry

University of Hawaii at Manoa

Dr. Phitsamay Sychitkokhong Uy

University of Massachusetts, Lowell

\section{Book Review Editor}

Dr. Vichet Chhuon

University of Minnesota

\section{Creative Works Editor \\ Bryan Thao Worra \\ Lao Assistance Center \\ Journal Manager \\ Marshall Klassen \\ Purdue University}

\section{Editorial Review Board}

Dr. Steve Arounsack

California State University, Stanislaus

Dr. Sovicheth Boun

The State University of New York at Fredonia

Dr. George Chigas

University of Massachusetts, Lowell

Dr. Hien Duc Do

San Jose State University
Dr. Carl L. Bankston III

Tulane University

Dr. Phala Chea

Lowell Public Schools

Dr. Loan Dao

University of Massachusetts, Boston

Dr. Changming Duan

University of Missouri, Kansas City

Journal of Southeast Asian American Education \& Advancement, Vol. 10 Iss. 2 Special Issue (2015) 


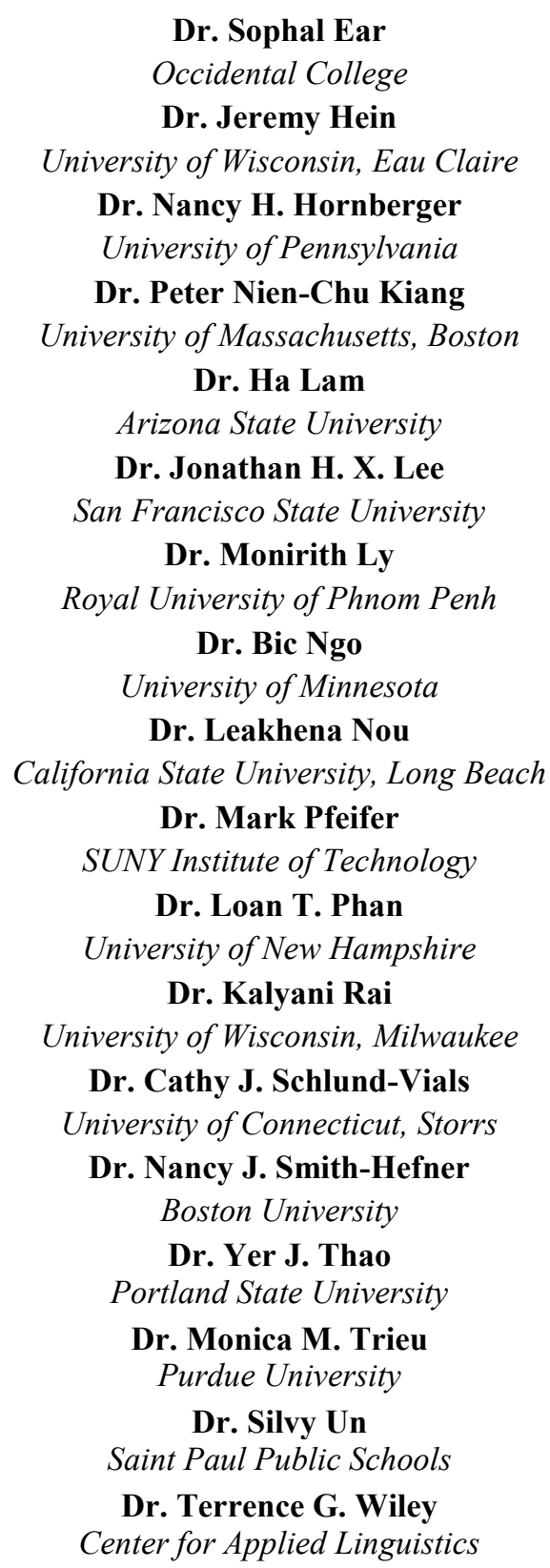

Dr. Sophal Ear

ccidental College

Dr. Jeremy Hein

Dr. Nancy H. Hornberger

University of Pennsylvania

Dr. Peter Nien-Chu Kiang

Dr. Ha Lam

Arizona State University

Dr. Jonathan H. X. Lee

Dr. Monirith Ly

Dr. Bic Ngo

niversity of Minnesota

State University, Long Beach

Y Institute of Technology

Dr. Kalyani Rai

iversity of Wisconsin, Milwauke

niversity of Connecticut, Storrs

Boston University

Portland State University

Dr. Monica M. Trieu

Purdue Univensity

Saint Paul Public Schools

Center for Applied Linguistics

\author{
Dr. Sothy Eng \\ Lehigh University \\ Dr. Vincent K. Her \\ University of Wisconsin, Eau Claire \\ Dr. Peter Tan Keo \\ New York University \\ Dr. Kevin K. Kumashiro \\ University of San Francisco \\ Dr. Ravy Lao \\ California State University, Los Angeles \\ Dr. Stacey Lee \\ University of Wisconsin, Madison \\ Dr. Sue Needham \\ California State University, Dominguez Hills \\ Dr. Max Niedzwiecki \\ Daylight Consulting Group \\ Dr. Clara Park \\ California State University, Northridge \\ Dr. Giang Pham \\ University of Massachusetts \\ Dr. Karen Quintiliani \\ California State University, Long Beach \\ Dr. Angela Reyes \\ Hunter College, The City University of New York \\ Dr. Fay Shin \\ California State University, Long Beach \\ Dr. Christine Su \\ Ohio University \\ Dr. Alisia Tran \\ Arizona State University \\ Dr. Khatharya Um \\ University of California, Berkeley \\ Dr. Linda Trinh Vo \\ University of California, Irvine \\ Dr. Yang Sao Xiong \\ University of Wisconsin-Madison
}

Dr. Zha Blong Xiong

University of Minnesota

\section{Doctoral Student Editorial Review Board}

\author{
Virak Chan \\ University of Texas at San Antonio \\ Annie BichLoan Duong \\ San Joaquin County Office of Education \\ Hoa Nha Nguyen \\ Boston College
}

\author{
Keo Chea-Young \\ University of Pennsylvania \\ Dung Minh Mao \\ University of Minnesota \\ Thien-Huong Ninh \\ University of Southern California
}

Journal of Southeast Asian American Education \& Advancement, Vol. 10 Iss. 2 Special Issue (2015) 
Journal of Southeast Asian American Education and Advancement, Vol. 10 [2015], Iss. 2, Art. 4

Surla, Poon - Visualizing Social Influences On College Choice

\author{
Malaphone Phommasa \\ University of California, Santa Barbara \\ Molly Wiebie \\ The University of Texas at Austin
}

\author{
Krissyvan Truong \\ Claremont Graduate University \\ Soua Xiong \\ San Diego State University \& \\ Claremont Graduate University
}

Anna H. Yang

University of Georgia

Journal of Southeast Asian American Education \& Advancement, Vol. 10 Iss. 2 Special Issue (2015) 